\title{
VARIASI BAKTERI PADA PENDERITA INFEKSI SALURAN KEMIH (ISK)
}

\author{
Muhammad Yashir, Apriani \\ STIKes Kesetiakawanan Sosial Indonesia, 1.2 Teknologi Laboratorium Medis \\ aapriani1504@gmail.com
}

\begin{abstract}
Urinary Tract Infection (UTI) is the second most common infectious disease after respiratory tract infection and as many as 8.3 million cases are reported per year. In Indonesia the prevalence of UTI ranges from 5-15\% and the number of UTI patients reaches $90-100$ cases per 100,000 population per year. gold standard of ISK proof by performing microbiological examination that is urine culture and routine urinalysis examination of dyeing method. This study aims to find out the description of urine culture laboratory results on leukocyte esterase and Erythrocytes, and to see the presence of bacterial variation in isk sufferers at Atmajaya Hospital, North Jakarta. Research Methods Descriptive analysis of 33 samples or respondents of all ages without limitation in Microbiology Laboratory Atmajaya Hospital November - December 2017. The results of the number of female respondents $(52 \%)$ more than men $(48 \%)$. The incidence of UTI was increased in patients over 40 years of age, $41-60$ years (10 cases), and $>60$ years (10 cases). From this study, Escherichia coli $(31 \%)$ is the most common microorganism that causes UTI.
\end{abstract}

Keywords: Urinary tract infections, microorganisms, urine cultures

\begin{abstract}
Abstrak : Infeksi Saluran Kemih (ISK) merupakan penyakit infeksi kedua tersering setelah infeksi saluran pernafasan dan sebanyak 8,3 juta kasus dilaporkan per tahun. Di Indonesia prevalensi ISK berkisar antara 5-15\% dan jumlah penderita ISK mencapai 90-100 kasus per 100.000 penduduk per tahun. baku emas pembuktian ISK dengan melakukan pemeriksaan mikrobiologi yaitu kultur urin dan pemeriksaan urinalisis rutin metode carik celup. Penelitian ini bertujuan untuk mengetahui gambaran hasil laboratorium kultur urin terhadap leukosit esterase dan Eritrosit, dan untuk melihat adanya variasi bakteri pada penderita isk di RS Atmajaya Jakarta Utara.Metode Penelitian studi analisa deskriptif dari 33 sampel atau responden semua umur tanpa batasan di Laboratorium Mikrobiologi RS Atmajaya November - Desember 2017. Hasil penelitian jumlah responden perempuan (52\%) lebih banyak dibanding laki-laki (48\%). Angka kejadian ISK meningkat pada pasien kelompok umur diatas 40 tahun yaitu 41-60 tahun (10 kasus), dan >60 tahun (10 kasus). Dari penelitian ini, Escherichia coli (31\%) merupakan mikroorganisme tersering yang menyebabkan ISK.
\end{abstract}

Kata kunci : Infeksi Saluran Kemih, Mikroorganisme , Kultur Urin.

Infeksi Saluran Kemih (ISK) adalah untuk mengumpul dan menyimpan urin infeksi akibat berkembang biaknya serta organ yang mengeluarkan urin dari mikroorganisme di dalam saluran kemih tubuh, yaitu ginjal, ureter, kandung kemih manusia. Saluran kemih manusia dan uretra. Penyakit ISK merupakan merupakan organ-organ yang bekerja masalah kesehatan masyarakat di 
Indonesia yang perlu mendapatkan perhatian yang serius. Prevalensi ISK di populasi umum di Indonesia berkisar antara 5-15\% (Subandiyah, 2004). Data dari Departemen Kesehatan RI tahun 2014 menunjukkan bahwa jumlah penderita penyakit ISK mencapai 90-100 kasus per 100.000 penduduk per tahun. ISK merupakan penyakit infeksi yang menempati urutan kedua dan masuk 10 besar penyakit dengan angka kejadian tertinggi.(Subandiyah,2004) Pada penelitian di Indonesia yang dilakukan pada penderita diabetes didapatkan kejadian ISK sebesar $47 \%$, pasien dengan batu ginjal $41 \%$, dan pasien dengan obstruksi saluran kemih sebesar $20 \%$. Dari $40 \%$ penderita yang terpasang kateter mendapatkan infeksi nosokomial dan bakteriuri sebanyak 26\% (Ariwijaya, 2007). Menurut National Kidney and Urologic Diseases Information Clearinghouse (NKUDIC), ISK merupakan penyakit infeksi kedua tersering setelah infeksi saluran pernafasan dan sebanyak 8,3 juta kasus dilaporkan per tahun (WHO, 2013).

Faktor-faktor yang menyebabkan infeksi saluran kemih antara lain usia, sistem imun, prosedur pemasangan kateter, perawatan kateter dan lama kateter terpasang. ISK dapat terjadi baik pada pria maupun wanita dari semua umur, dan dari kedua jenis kelamin ternyata wanita lebih sering menderita infeksi daripada pria. Angka kejadian bakteriuria di wanita meningkat sesuai dengan bertambahnya usia dan aktifitas seksual. Di kelompok wanita yang tidak menikah angka kejadian ISK lebih rendah dibandingkan dengan kelompok yang sudah menikah. Lebih kurang $35 \%$ kaum wanita selama hidupnya pernah menderita ISK akut dan umur tersering adalah di kelompok umur antara 20 sampai 50 tahun, sedangkan pada laki-laki hal tersebut sering terjadI setelah usia 50 tahun ke atas (Tessy, 2001 dan Kayser, 2005)

ISK dapat disebabkan oleh berbagai macam mikroorganisme, dan terbanyak adalah bakteri. Kuman penyebab ISK pada umumnya adalah kuman yang berasal dari flora normal usus dan hidup secara komensal di introitus vagina,prepusium penis, kulit perineum, dan sekitar anus. Penyebab lain meskipun jarang ditemukan adalah jamur, dan virus. Berdasarkan hasil pemeriksaan biakan urin kebanyakan ISK disebabkan oleh bakteri Gram negatif aerob yang biasa ditemukan di saluran pencernaan (Enterobacteriaceae), dan jarang disebabkan oleh bakteri anaerob (Tessy, 
2001) Salah satu penelitian di Australia mengatakan bahwa $95 \%$ pasien yang menderita infeksi saluran kemih (ISK) disebabkan oleh bakteri Escherichia coli (Therapeutic guidelines ltd., 2006)

Berdasarkan hal tersebut di atas, maka perlu dilakukan penelitian untuk mengetahui variasi bakteri apa saja yang menjadi penyebab ISK, yang merupakan hal penting dalam menunjang diagnosa dokter / klinisi,dan mengevaluasi kualitas pelayanan kesehatan.

\section{BAHAN DAN CARA KERJA}

Jenis Penelitian yang akan digunakan dalam penelitian ini merupakan penelitian analitik deskriptif. Sampel penelitian adalah semua pasien suspect ISK yang akan dilakukan pemeriksaan kultur urin di Laboratorium Mikrobiologi RS.Atmajaya periode November Desember 2017 .

Bahan untuk sampel urin diambil dari Urin porsi tengah (Midstream urine). Sebelumnya diberikan penjelasan mengenai cara pengambilan urin untuk menghindari kontaminasi. Lakukan pemeriksaan urinalisis untuk melihat adanya leukosit esterase dan eritrosit. Jika terdapat leukosituria dan hematuria, pemeriksaan dilanjutkan ke isolasi dan identifikasi. Bakteri selanjutnya di inokulasi pada media Agar Darah dan Mac Conkey Agar dan diinkubasi pada suhu $37^{\circ} \mathrm{C}$ selama 24 jam. Jika ada pertumbuhan kemudian lakukan hitung koloni (cfu/ml) Lakukan pengecatan Gram untuk mendapatkan sifat Gram dari kuman yang ditemukan. Selanjutnya dilakukan identifikasi jenis bakteri penyebab ISK.

\section{HASIL}

Berdasarkan penelitian yang dilakukan di Laboratorium Mikrobiologi RS Atmajaya selama periode November Desember 2017 di dapatkan jumlah sampel sebanyak 33 pasien ISK. Distribusi sampel berdasarkan umur didapatkan kasus ISK lebih banyak menyerang perempuan yaitu 17 kasus $(52 \%)$ dan golongan umur terbanyak adalah diatas 40 tahun yaitu 20 kasus (60 \%) (Tabel 1). Berdasarkan jenis kelamin pada pasien ISK diketahui bahwa sebagian besar pasien ISK berjenis kelamin perempuan yaitu sebanyak 17 pasien (52\%). Sementara pasien berjenis kelamin laki-laki sebanyak 16 pasien (48 $\%)$

Tabel 1.Distribusi Rasio umur pasien ISK

\begin{tabular}{ccc}
\hline Umur (Tahun) & Jumlah (n) & Persentase (\%) \\
\hline$<1$ & 1 & 3 \\
$1-20$ & 5 & 15 \\
$21-40$ & 7 & 22 \\
$41-60$ & 10 & 30 \\
$>60$ & 10 & 30 \\
\hline
\end{tabular}




\begin{tabular}{lll}
\hline Total & 33 & 100 \\
\hline
\end{tabular}

Berdasarkan hasil pemeriksaan, Dari 33 sampel urin yang diperiksa menunjukkan adanya pertumbuhan bakteriuria yang bermakna (jumlah koloni $>10^{5} \mathrm{cfu} / \mathrm{ml}$ urin porsi tengah). Dari sebanyak sampel tersebut, teridentifikasi 12 jenis bakteri yang ditemukan dari hasil kultur urin pasien ISK dan 1 jenis fungi. Sebagian besar adalah bakteri Gram negatif (9 jenis, $69 \%$ ), sisanya adalah bakteri Gram positif (3 jenis, $23 \%$ ) dan fungi (1 jenis, 8\%). Dari hasil pemeriksaan tersebut dapat disimpulkan bahwa mikroorganisme penyebab ISK terbanyak adalah mikroorganisme Escherichia coli (31\%), kemudian mikroorganisme Klebsiella pneumonia (24\%) dan mikroorganisme Enterococcus faecalis (9\%) (Tabel 2)

Tabel 2. Jenis-jenis bakteri penyebab ISK

\begin{tabular}{|c|c|c|c|c|}
\hline No & $\begin{array}{l}\text { Mikroorgan } \\
\text { isme }\end{array}$ & $\begin{array}{l}\mathrm{Ju} \\
\mathrm{ml} \\
\mathrm{ah} \\
(\mathrm{n})\end{array}$ & $\begin{array}{l}\text { Persen } \\
\text { tase } \\
(\%)\end{array}$ & $\begin{array}{c}\text { Kelomp } \\
\text { ok } \\
\text { bakteri }\end{array}$ \\
\hline 1 & $\begin{array}{l}\text { Escherichia } \\
\text { coli }\end{array}$ & 10 & 31 & $\begin{array}{l}\text { Bakteri } \\
\text { gram }\end{array}$ \\
\hline 2 & $\begin{array}{l}\text { Klebsiella } \\
\text { pneumoniae }\end{array}$ & 8 & 24 & negatif \\
\hline 3 & $\begin{array}{l}\text { Acinetobact } \\
\text { er } \\
\text { baumannii }\end{array}$ & 2 & 6 & \\
\hline 4 & $\begin{array}{l}\text { Pseudomon } \\
\text { as } \\
\text { aeruginosa }\end{array}$ & 1 & 3 & \\
\hline 5 & $\begin{array}{l}\text { Pseudomon } \\
\text { as } \\
\text { agglomeran } \\
s\end{array}$ & 1 & 3 & \\
\hline 6 & $\begin{array}{l}\text { Serratia } \\
\text { rubidaea }\end{array}$ & 1 & 3 & \\
\hline 7 & $\begin{array}{l}\text { Pseudomon } \\
\text { as } \\
\text { fluorescens }\end{array}$ & 1 & 3 & \\
\hline
\end{tabular}

\begin{tabular}{|c|c|c|c|c|}
\hline 8 & $\begin{array}{l}\text { Citrobacter } \\
\text { braakii }\end{array}$ & 1 & 3 & \\
\hline 9 & $\begin{array}{l}\text { Morganella } \\
\text { morganii }\end{array}$ & 1 & 3 & \\
\hline 10 & $\begin{array}{l}\text { Enterococc } \\
\text { us faecalis }\end{array}$ & 3 & 9 & $\begin{array}{l}\text { Bakteri } \\
\text { gram }\end{array}$ \\
\hline 11 & $\begin{array}{l}\text { Enterococc } \\
\text { us } \\
\text { gallinarum }\end{array}$ & 1 & 3 & positif \\
\hline 12 & $\begin{array}{l}\text { Staphylococ } \\
\text { cus aureus }\end{array}$ & 1 & 3 & \\
\hline 13 & $\begin{array}{l}\text { Candida } s p \\
\text { Total }\end{array}$ & $\begin{array}{c}2 \\
33 \\
\end{array}$ & $\begin{array}{c}6 \\
100 \\
\end{array}$ & Fungi \\
\hline
\end{tabular}

\section{PEMBAHASAN}

Penderita ISK di Instalasi Rawat Inap dan Rawat Jalan RS.Atmajaya periode November-Desember 2017 , didapatkan 33 sampel penelitian dengan 33 hasil kultur urin positif.

Distribusi kasus ISK berdasarkan umur, ditemukan peningkatan angka kejadian ISK yaitu pada kelompok di atas umur 40 tahun dari 20 kasus ISK (60\%). Hal ini menunjukkan bahwa angka kejadian ISK meningkat seiring bertambahnya usia. ISK sering muncul pada orang-orang yang lebih tua baik dalam komunitas dan dalam perawatan jangka panjang. Sejumlah faktor predisposisi yang mengakibatkan ISK pada orang-orang yang lebih tua, antara lain penyakit prostat pada pria. Pada perempuan, defisiensi hormon estrogen post menopause sering dikaitkan dengan angka kejadian ISK (Beveridge,et al. 2011). Pada usia lanjut terjadinya ISK ini sering disebabkan karena adanya: (a) Sisa urin dalam kandung kemih yang 
meningkat akibat pengosongan kandung kemih yang tidak lengkap atau kurang efektif, (b) Mobilitas menurun, (c) Nutrisi yang sering kurang baik, (d) System imunnitas yng menurun, (e) Adanya hambatan pada saluran urin, (f) Hilangnya efek bakterisid dari sekresi prostat.

Sisa urin dalam kandung kemih yang meningkat tersebut mengakibatkan distensi yang berlebihan sehingga menimbulkan nyeri, keadaan ini mengakibatkan penurunan resistensi terhadap invasi bakteri dan residu kemih menjadi media pertumbuhan bakteri yang selanjutnya akan mengakibatkan gangguan fungsi ginjal sendiri, kemudian keadaan ini secara hematogen menyebar ke suluruh traktus urinarius. Selain itu, beberapa hal yang menjadi predisposisi ISK, antara lain: adanya obstruksi aliran kemih proksimal yang mengakibtakan penimbunan cairan bertekanan dalam pelvis ginjal dan ureter yang disebut sebagai hidronefroses. Penyebab umum obstruksi adalah: jaringan parut ginjal, batu, neoplasma dan hipertrofi prostate yang sering ditemukan pada laki-laki diatas usia 60 tahun.

Dilihat dari distribusi kasus ISK berdasarkan jenis kelamin, perempuan lebih sering menderita ISK daripada lakilaki yaitu sebanyak 17 pasien perempuan
(52\%), dibandingkan dengan pasien lakilaki yang hanya berjumlah 16 pasien (48 \%) dari total sampel. Prevalensi dan insidensi tersebut dikarenakan faktor klinis seperti perbedaan anatomi , efek hormonal dan pola perilaku (Astal, 2009). Hal ini sesuai dengan hasil penelitian yang dilaporkan oleh Samirah,dkk. (2006) yang melaporkan bahwa perempuan lebih sering menderita ISK dibandingkan lakilaki.

ISK adalah kondisi medis umum yang mengakibatkan angka morbiditas dan mortalitas yang meningkat signifikan khususnya pada perempuan sekitar 50$60 \%$ akan mengalami ISK setidaknya satu kali dalam hidup mereka. Banyak nya perempuan yang menderita ISK dari pada laki-laki dikarenakan anatomi uretra perempuan memiliki uretra pendek $2-3 \mathrm{~cm}$ sehingga bakteri kontaminan lebih mudah masuk menuju saluran kemih, selain itu juga karena letak saluran kemih perempuan lebih dekat dengan rektal sehingga mempermudah kuman-kuman masuk ke saluran kemih, sedangkan lakilaki memiliki uretra panjang $15-18 \mathrm{~cm}$ yang memiliki cairan prostat dimana cairan tersebut bersifat bakterisidal sebagai pelindung terhadap infeksi oleh bakteri (Coyle dan Prince, 2005 dan Corwin, 2008). Kehamilan dikaitkan 
dengan kejadian bakteriuria asimptomatis (4\%-7\%) dan pielonefritis $(0,5 \%-2 \%)$ karena pengaruh hormonal yang menyebabkan perubahan pada fungsi ginjal dibandingkan sebelum kehamilan.

Setelah menopause, $10 \%$ perempuan mengalami ISK satu kali setiap tahun dikarenakan sekresi estrogen yang berfungsi sebagai pencegah kolonisasi uretra vaginal dari Enterobacteriaceae mengalami penurunan yang signifikan, maka berbagai jaringan menjadi lebih tipis dan rapuh sehingga lebih mudah terinfeksi (Nico, 2004). Aktifitas seksual juga sepertinya berkaitan dengan berkembangnya rekurensi ISK pada perempuan pre-menopause (Minardi, 2011).

Kolonisasi uretra dan daerah introitus vagina pada Saluran kemih dalam keadaan normal umumnya tidak mengandung mikroorganisme kecuali pada bagian distal uretra yang biasanya juga dihuni oleh bakteri normal kulit seperti basil difteroid, streptpkokus. Di samping bakteri normal flora kulit, pada wanita, daerah $1 / 3$ bagian distal uretra ini disertai jaringan periuretral dan vestibula vaginalis yang juga banyak dihuni oleh bakteri yang berasal dari usus karena letak usus tidak jauh dari tempat tersebut. Pada wanita, kuman penghuni terbanyak pada daerah tersebut adalah E.coli di samping enterobacter dan S.faecalis. Kolonisasi E.coli pada wanita didaerah tersebut diduga karena; (a) adanya perubahan flora normal di daerah perineum, (b) Berkurangnya antibodi local, (c) Bertambahnya daya lekat organisme pada sel epitel wanita.

\section{Enterobacteriaceae adalah keluarga} bakteri yang bertanggung jawab pada sekitar 50\% infeksi nosokomial. Penyebab paling sering menyebabkan infeksi nosokomial oleh keluarga bakteri ini adalah E. coli, Klebsiella, Enterobacter, Proteus, Providencia, dan Serratia marcencens (Holt,GJ.et.al 1994). Selain itu, E. coli adalah penyebab utama infeksi saluran kemih (urinary tract infection/UTI) dan juga dapat menyebabkan meningitis akut, pneumonia, infeksi intra-abdominal, infeksi enterik, dan lain-lain.

Pemeriksaan sampel yang dilakukan pada penelitian ini menunjukkan adanya pertumbuhan mikroorganisme. Dari sampel yang diperiksa tersebut ditemukan bahwa Escherichia coli merupakan mikroorganisme terbanyak penyebab ISK secara umum yang ditemukan dalam penelitian ini (10 kasus (31 \%)). Hal ini sesuai dengan hasil penelitian yang dilaporkan oleh Samirah,dkk. (2006) dan 
Mahest et al. (2011) yang menemukan Escherichia coli sebagai jenis bakteri penyebab ISK tersering. Hasil penelitian lain oleh Refdanita dkk. Saluran kemih merupakan tempat yang paling umum dari infeksi E.coli,dan lebih dari $90 \%$ ISK tanpa komplikasi disebabkan infeksi E.coli. Tingkat kekambuhan setelah infeksi E.coli pertama adalah $44 \%$ selama 12 bulan. Uropathogenic Escherichia coli (UPEC) adalah agen penyebab sebagian besar infeksi saluran kemih (ISK), termasuk sistitis dan pielonefritis, dan komplikasi infeksi yang dapat menyebabkan gagal ginjal akut pada individu sehat serta pada pasien transplantasi ginjal (Bien J.et al. 2012).

\section{KESIMPULAN}

Berdasarkan hasil penelitian variasi bakteri pada penderita ISK didapat sejumlah mikroorganisme yang

\section{DAFTAR RUJUKAN}

Astal, Z.Y.E. 2009. Ciprofloxacin Resistance Among Uropathogen, in Khan A.U.,Current Trends in Antibiotic Resistance in Infectious Diseases, I.K.International Publishing House,New Delhi, 112.

Beveridge, L,Davey P.G, Phillips G,McMurdo M.E.T. 2011. Optimal management of urinary tract infection in older people. Dovepress journal. 6:173-74 teridentifikasi dalam sampel urin pada penderita ISK. Jenis mikroorganisme terbanyak yang ditemukan adalah Bakteri jenis Gram Negatif golongan Enterobacteriaceae. Mikroorganisme penyebab ISK terbanyak berturut-turut adalah Escherichia coli (31\%), Klebsiella pneumonia (24\%) dan Enterococcus faecalis $(9 \%)$.

Perlu dilakukan penelitian secara berkala untuk melihat pola bakteri dan sensitivitasnya, supaya untuk mengantisipasi sering terjadinya pergeseran pola kuman dan resistensi tubuh terhadap antimikroba, untuk tenaga analis kesehatan agar dapat melakukan promosi pelayanan kesehatan dengan cara memberikan edukasi kepada masyarakat mengenai cara pencegahan penyakit ISK terutama pada kelompok yang rentan yaitu perempuan, wanita hamil dan orang tua.

Coyle, E.A, Prince, R.A. 2005. Urinary Tract Infection. Pharmacotherapy: A Pathophysiologic Approach. 6th ed. USA: The McGraw-Hill Companies. 2081-95.

Corwin, E.J. 2008. Handbook of Pathophysiology, $3^{\text {nd }}$ Edition, diterjemahkan oleh Nike Budhi Subekti, Egi Komara Yudha (editor), hal.718. EGC,Jakarta

Holt, G,J, Krieg, R.N, Sneath, H.A.P, Staley, HAP, Williams, T.S. 1994. Enterobacteriaceae. In: Bergey's manual of determinative 
bacteriology. International Edition. 9th ed. Maryland: Williams \& Wilkins, 179-80.

Kayser. 2005. Medical microbiology. 15th ed. London: Mosby, 7-20.

Minardi, D, d'Anzeo, G, Cantoro, D, Conti, A, Muzzonigro, G. 2011. Urinary tract infections in women: etiology and treatment options. International Journal of General Medicine, 4(1): 333-43.

Mahesh, E, Medha, Y, Indumathi, V.A, Kumar, P.S, Khan, M.W, Punith, K. 2011 Community-acquired urinary tract infection in the elderly BJMP, 4(1):407

Nico, A.L, K.Nefro, dkk. 2004. Kenali Jenis Penyakit dan Cara Penyembuhannya.Jakarta: PT.Elex Media Komputindo.

Refdanita, Maksum, Nurgani, dan Endang. 2004. Pola Kepekaan Kuman Terhadap Antibiotika di Ruang Rawat Intensif Rumah
Sakit Fatmawati Jakarta Tahun 2001-2004, Makara Kesehatan, 8(2),41-50.

Subandiyah, K. 2004. Pola dan sensitifitas terhadap antibiotik bakteri penyebab infeksi saluran kemih anak di RSU dr.Saiful Anwar,Malang.

Samirah, Darwati, Windarwati, Hardjoeno. 2006. Pola dan sensitivitas kuman pada penderita infeksi saluran kemih. Indonesian journal of clinical pathology and medical laboratory, 110-11.

Tessy, A, Ardaya, Suwanto. 2001. Buku Ajar Ilmu Penyakit Dalam Jilid II. Edisi 3. Jakarta: Balai Penerbit FK UI, 369-76.

Therapeutic Guidelines 1td. Urinary Tract Infections. In eTG complete (internet).(2006) (Accessed 17 January 2010).

WHO. 2013. Kesehatan Reproduksi Wanita ISK.Jakarta; Salemba Medika 